\title{
What is the optimal type of physical activity to enhance health?
}

School of Physical and Health Education and Department of Preventive Medicine and Biostatistics, Faculty of Medicine, University of Toronto, and Health Studies Programme, Brock University, St. Catharines, Ontario, Canada

R J Shephard

Correspondence to: Professor Roy J Shephard, School of Physical and Health Education, University of Toronto, 320 Huron St, Toronto, ON M5S 1A1, Canada.

Accepted for publication 12 March 1997

Roy J Shephard

\section{Summary}

This review examines the potential of active daily living as a means of gaining the cardiovascular and health rewards previously sought through vigorous aerobic fitness programmes. Cross-sectional studies of occupational and leisure activity show encouraging associations between such activity and good health; in workers, the gross intensity of effort needed for health benefits has seemed to be 20 $\mathrm{kJ} / \mathrm{min}$. There has been less unanimity on the threshold intensity needed in leisure activities, but various recent "position statements" have decreased the recommendation to $50 \%$ of an individual's maximal oxygen intake, sustained for one hour three to five times per week. Lifestyle activities such as walking seem likely to reach this intensity in older individuals, but are unlikely to do so in young adults. A growing number of controlled longitudinal studies of walking programmes have demonstrated gains in aerobic fitness, modest reductions in blood pressure, improvements in lipid profile, increased bone density, and enhanced mood state, with less consistent reductions of body fat. However, gains have been greatest in the elderly, sedentary, and obese populations. The main component of active living, fast walking, seems likely to enhance health in such populations, but it is unlikely to be effective in young adults who are in good initial health.

\section{Introduction}

A number of governments, including those of the USA and Canada, are currently changing the emphasis of their health promotional programmes from the advocacy of vigorous aerobic exercise to the concept of "active living"- that is, the incorporation of moderate physical activity into everyday living. It is thus important to review the effectiveness of this tactic relative to the structured exercise classes of traditional fitness programmes.

\section{ACTIVITY PATTERN AND HEALTH BENEFITS}

It is now well accepted that the habit of regular physical activity reduces an individual's ageadjusted risk of both all-cause and cardiovascular disease specific mortality. ${ }^{1-13}$ A number of recent reports ${ }^{3-9}$ and reviews ${ }^{12}{ }^{2-10}$ have further suggested that the largest gain in prognosis is realised as a person progresses from the lowest to the next lowest level of physical activity or physical fitness. Occasional dissenting reports still suggest a need for vigorous physical activity. ${ }^{14-17}$ Nevertheless, many policy makers now argue that the health of sedentary late twentieth century adults can be improved through the adoption of quite low levels of leisure activity, possibly of insufficient intensity to augment traditional markers of physical fitness such as the maximal oxygen intake.

If such expectations prove well founded, then there is justification in shifting the emphasis of health promotion programmes from costly "high-tech" structured and supervised classes of aerobic exercise, with their inherent problems of limited recruitment and very high drop out rates, ${ }^{18} 19$ to the encouragement of an active daily lifestyle, including such pursuits as walking, cycling, and gardening.

\section{ACTIVITY PATTERNS AND PSYCHOSOCIAL ISSUES}

The impact of the recommended activity pattern upon recruitment, adherence, and programme costs will not be explored in any detail. Nevertheless, we may note that it is easier for a person who is currently sedentary to adopt and to maintain modest lifestyle activities such as walking than to participate in a structured programme of vigorous aerobic exercise.

Moreover, if a person elects the vigorous pursuit of daily activities, rather than attendance at a specific exercise class, then the costs of special equipment, clothing, and facilities are largely avoided, and the time demands are also much reduced. Many of those who currently fail to exercise regularly claim that a lack of time, a lack of facilities, and cost are major reasons why they remain sedentary. ${ }^{20}$ In consequence, programmes that emphasise unsupervised activity such as daily walking can sometimes be more effective than supervised structured exercise classes. ${ }^{1921}$ Indeed, very simple local interventions such as posters recommending use of the stairs ${ }^{22}$ or a programme that advocates commuting by bicycle or on foot ${ }^{24}$ sometimes augment daily physical activity by a substantial amount, although attempts to incorporate a less specific vision of "active living" into a broader community-wide health promotion campaign have had only limited success. ${ }^{25}$

\section{CURRENT ISSUES REGARDING ACTIVITY PATTERNS} AND HEALTH

Taking as our criterion of programme effectiveness a reduction in cardiovascular risk factors rather than an increase in aerobic fitness, the choice between moderate lifestyle activities and a more intensive and formal exercise programme raises several important research issues. 
(1) Is adoption of the currently recommended "active daily lifestyle" correlated with indicators of future good health? If so, can issues of selection bias be excluded by appropriate longitudinal experiments?

(2) What is the minimal weekly amount of physical activity needed to yield clinically significant health benefits? Is this minimum "dose" of exercise consistent for various types of physical activity, and for population groups that differ in age, gender, socioeconomic status, and ethnic background?

(3) What weekly quantity of physical activity is likely to be generated through employment in a "heavy" occupation or the encouragement of active living?

(4) How do community gains in health related fitness compare between programmes that have focused upon encouraging an overall active lifestyle and other initiatives that have emphasised participation in formal structured exercise programmes?

\section{Associations between an overall active lifestyle and health indicators}

Cross-sectional studies of occupation and leisure have provided many encouraging reports of associations between an active lifestyle and the maintenance of good cardiovascular health. Longitudinal studies generally support the inferences drawn from the cross-sectional data, and in particular a growing number of reports indicate health benefits from the adoption of rapid walking.

\section{OCCUPATIONAL STUDIES}

Cross-sectional comparisons between physically demanding and sedentary occupations have almost without exception demonstrated an association between the physical demands of employment and protection against ischaemic heart disease. ${ }^{26}$ However, such observations are open to the important objection that the personnel engaged to perform "heavy" work are either recruited by management ${ }^{27}$ or self-selected ${ }^{28}$ in terms of personal health and interest in an active lifestyle.

Brunner and Manelis ${ }^{29}$ claimed that the problem of self-selection was overcome in their study of an Israeli kibbutz, where residents were given little choice in their assigned duties. ${ }^{29}$ But even in this special situation, it is difficult to believe that the management committee took no account of physique and physical abilities when deciding what work any given person should undertake.

\section{STUDIES OF ACTIVE LEISURE}

Many reports show a positive association between self reported leisure activity and cardiac health. ${ }^{122630}$ In general, the stronger the study design, the larger the gradient in risks of all-cause and cardiac death. ${ }^{26}$

The well documented impact of self selected exercise upon cardiac risk factors ${ }^{31-34}$ can be illustrated by some recent data from our laboratory. ${ }^{35}$ Subjects were questioned about
Table 1 Gradients of established cardiac risk factors with self reported physical activity. Based on the data of Shephard and Bouchard ${ }^{112}$

\begin{tabular}{|c|c|c|c|}
\hline & Low & Moderate & High \\
\hline \multicolumn{4}{|l|}{ Perceived intensity } \\
\hline \multicolumn{4}{|l|}{ Men } \\
\hline Total skinfolds $(\mathrm{mm})$ & 114 & 104 & 98 \\
\hline HDL cholesterol $(\mathrm{mmol} / \mathrm{l})$ & 1.19 & 1.14 & 1.19 \\
\hline PWC $150(W / k g)$ & 1.69 & 1.73 & 1.95 \\
\hline Resting heart rate (beats/min) & 58 & 59 & 56 \\
\hline \multicolumn{4}{|l|}{ Women } \\
\hline Total skinfolds (mm) & 168 & 148 & 141 \\
\hline HDL cholesterol $(\mathrm{mmol} / \mathrm{l})$ & 1.35 & 1.46 & 1.43 \\
\hline PWC $150(W / k g)$ & 1.15 & 1.23 & 1.36 \\
\hline Resting heart rate (beats/min) & 67 & 62 & 63 \\
\hline \multicolumn{4}{|l|}{ Perceived frequency } \\
\hline \multicolumn{4}{|l|}{ Men } \\
\hline Total skinfolds (mm) & 104 & 96 & 101 \\
\hline HDL cholesterol $(\mathrm{mmol} / \mathrm{l})$ & 1.11 & 1.21 & 1.15 \\
\hline PWC $150(W / k g)$ & 1.79 & 1.73 & 1.79 \\
\hline Resting heart rate (beats/min) & 63 & 57 & 53 \\
\hline \multicolumn{4}{|l|}{ Women } \\
\hline Total skinfolds (mm) & 150 & 131 & 126 \\
\hline HDL cholesterol (mmol/l) & 1.36 & 1.53 & 1.56 \\
\hline PWC $150(W / k g)$ & 1.20 & 1.28 & 1.49 \\
\hline Resting heart rate (beats/min) & 65 & 61 & 61 \\
\hline
\end{tabular}

$\mathrm{HDL}=$ high density lipoprotein .

the frequency with which they engaged in demanding activity, the intensity of their active leisure pursuits, their perceived level of fitness, and their perceived level of physical activity relative to their peers. On each of these measures, differences between the least active quartile or tertile and the most active in terms of average skinfold thickness, high density lipoprotein (HDL) cholesterol, serum triglycerides, PWC 150, and resting heart rate (table 1) were as large as or larger than would have been expected in response to most structured exercise programmes. However, the problem remains that active leisure was self selected, so that at least a part of the observed gradient in cardiac risk factors could have had a constitutional origin.

\section{RANDOMISED LONGITUDINAL STUDIES}

There are fewer problems of initial subject selection in longitudinal studies where subjects are assigned randomly to a control group or a programme of enhanced physical activity.

Nevertheless, the volunteers for such experiments do tend to be young relatively fit non-smokers of high socioeconomic status. Even the findings for this subgroup of the population can be invalidated by a high drop out rate of unfit individuals from the experimental group, and/or a defection of fit subjects from the control group.

One recent randomised controlled trial of lifestyle activity found a $4.5 \%$ increase in aerobic power, a $10.3 \%$ increase in treadmill endurance time, and a $5 \%$ increase in HDL cholesterol in those who had been assigned to a ten week active commuting programme of walking or cycling. ${ }^{24}$

REPORTED RESPONSES TO WALKING

The major component of an active lifestyle is usually rapid walking. ${ }^{20}$ Many studies have demonstrated that walking programmes have a beneficial influence upon various indicators of good health (table 2). 
Table 2 Influence of walking programmes upon various measures of health status

\begin{tabular}{|c|c|c|c|c|c|}
\hline Health indicator & Sample & Programme & Design & Health improved & Reference \\
\hline \multirow[t]{11}{*}{ Blood pressure } & $107 \mathrm{M}$ aged $40-60$ & $14 \mathrm{wk}, 70-75 \% \mathrm{HRmax}$ & $\mathrm{Lc}$ & Yes & 36 \\
\hline & $65 \mathrm{M}, 297 \mathrm{~F}$ aged 47 & $21 \mathrm{wk}, 10000 \mathrm{steps} /$ day & $\mathrm{L}$ & Yes & 37 \\
\hline & $24 \mathrm{M}$ aged $40-56$ & 20wk, 63-76\% HRmax & $\mathrm{Lc}$ & Yes & 38 \\
\hline & $34 \mathrm{~F}$ aged $61-81$ & $8 \mathrm{wk}, 70-80 \% \mathrm{HRmax}$ & $\mathrm{Lc}$ & Yes & 39 \\
\hline & $46 \mathrm{~F}$ aged $20-40$ & $24 \mathrm{wk}, 56,67$ or $86 \% \max$ & Lc & Not at low intensity & 40 \\
\hline & $56 \mathrm{~F}$ aged 61.3 & $24 \mathrm{wk}, 60 \% \dot{\mathrm{V}}_{2}$ peak & $\mathrm{Lr}$ & Yes & 41 \\
\hline & $33 \mathrm{M} \& \mathrm{~F}$ aged 64 & $37 w k, 60 \% \dot{\mathrm{VO}}_{2} \max$ & $\overrightarrow{\mathrm{Lc}}$ & Yes & 42 \\
\hline & $34 M \& F$ aged 61 & $58 w k, 47,57 \%$ HRres & $\mathrm{Lc}$ & Yes & 43 \\
\hline & $M \& F$ aged $60-69$ & $4 \mathrm{wk}, 50 \% \dot{\mathrm{V}}_{2} \max$ & $\mathrm{L}$ & Yes & 44 \\
\hline & $\begin{array}{l}25 \mathrm{M}, 31 \mathrm{~F} \text { aged } \\
70-79\end{array}$ & $26 \mathrm{wk}, 75-85 \% \dot{\mathrm{V}}_{2} \max$ & $\mathrm{Lc}$ & Yes & 45 \\
\hline & $80 \mathrm{~F}$ aged $60-70$ & $26 \mathrm{wk}, 2 / \mathrm{wk} 16-45 \mathrm{~min}$ & $\mathrm{Lc}$ & No & 46 \\
\hline \multirow{11}{*}{ HDL cholesterol } & $107 \mathrm{M}$ aged $40-60$ & $14 \mathrm{wk}, 70-75 \% \mathrm{HRmax}$ & Lc & Yes & 36 \\
\hline & $34 \mathrm{~F}$ aged $61-81$ & $8 w k, 70-80 \%$ HRmax & $\mathrm{Lc}$ & Yes & 39 \\
\hline & $46 \mathrm{~F}$ aged $20-40$ & $24 w k, 56,67$ or $86 \% \max$ & $\mathrm{Lc}$ & Yes & 40 \\
\hline & $28 \mathrm{~F}$ aged 44.9 & $52 \mathrm{wk}, 60 \% \mathrm{HR} \max$ & Lc & Yes & 47 \\
\hline & $10 M$ aged $19-31$ & $16 \mathrm{wk}, 5.1 \mathrm{~km} / \mathrm{h}$ & $\mathrm{L}$ & Yes & 48 \\
\hline & Yes $35 \mathrm{M}$ aged 47.0 & Postal carriers & $\mathrm{C}$ & Yes & 49 \\
\hline & 3621 adults $(62 \% \mathrm{~F})$ & & $\mathrm{C}$ & $\begin{array}{l}\text { Yes (high, moderate but not low } \\
\text { duration) }\end{array}$ & 50 \\
\hline & $107 \mathrm{M}$ aged $30-55$ & $52 \mathrm{wk}, 70-85 \% \dot{\mathrm{V}}_{2} \max$ & $\mathrm{Lc}$ & Yes & 51 \\
\hline & $17 \mathrm{~F}$ & $11 w k, 71 \%$ HRmax & $\mathrm{L}$ & No & 52 \\
\hline & $255 \mathrm{~F}$ & $52 \mathrm{wk}, 6.4-7.2 \mathrm{~km} / \mathrm{h}$ & $\bar{L}$ & No & 53 \\
\hline & post-menopause & & & & \\
\hline \multirow{14}{*}{ Body fat/body mass } & $65 \mathrm{M}, 297 \mathrm{~F}$ aged 47 & $21 \mathrm{wk} 10000 \mathrm{steps} /$ day & $\mathrm{L}$ & Yes & 37 \\
\hline & $26 \mathrm{M}$ aged $40-56$ & $20 \mathrm{wk}, 63-76 \% \mathrm{HRmax}$ & Lc & Yes & 38 \\
\hline & $107 \mathrm{M}$ aged $40-60$ & $14 \mathrm{wk}, 70-75 \% \mathrm{HR} \max$ & $\mathrm{Lc}$ & No & 36 \\
\hline & $46 \mathrm{~F}$ aged $20-40$ & $24 w k, 56,67$ or $86 \% \max$ & $\mathrm{Lc}$ & Not low intensity & 40 \\
\hline & $80 \mathrm{~F}$ aged $60-70$ & $26 \mathrm{wk}, 2 /$ wk $16-45 \mathrm{~min}$ & $\mathrm{Lc}$ & No & 46 \\
\hline & $6 \mathrm{M}$ aged $19-31$ & $16 \mathrm{wk}, 5.1 \mathrm{~km} / \mathrm{h}$ & $\mathrm{L}$ & Yes & 48 \\
\hline & $81 \mathrm{M}$ aged $30-55$ & $52 \mathrm{wk}, 70-85 \% \max$ & Lc & Yes & 51 \\
\hline & $17 \mathrm{~F}$ aged $20-40$ & $11 \mathrm{wk}, 71 \% \mathrm{HRmax}$ & $\mathrm{L}$ & No & 52 \\
\hline & $44 \mathrm{~F}$ aged 44.9 & $52 \mathrm{wk}, 6.5 \mathrm{~km} / \mathrm{h}$ & $\mathrm{Lc}$ & No & 55 \\
\hline & $14 \mathrm{M}, 1 \mathrm{~F}$ aged 16 & $13 \mathrm{wk}, 80 \% \mathrm{HR} \max$ & $\mathrm{L}$ & Yes & 56 \\
\hline & $35 \mathrm{~F}$ aged $25-45$ & $15 \mathrm{wk}, 5 / \mathrm{wk} 45 \mathrm{~min}$ & $\mathrm{Lc}$ & No & 58 \\
\hline & $30 M$ aged $52-88$ & $6 \mathrm{wk}$, mixed programme & $\mathrm{L}$ & Yes & 59 \\
\hline & $7 \mathrm{M}$ aged $52-88$ & $42 \mathrm{wk}$, mixed programme & $\mathrm{L}$ & No & 59 \\
\hline & $23 \mathrm{~F}$ aged $57-79$ & $12 \mathrm{wk}$, mixed programme & $\mathrm{Lc}$ & No & 60 \\
\hline \multirow{15}{*}{ Aerobic power } & $107 \mathrm{M}$ aged $40-60$ & $14 \mathrm{wk}, 4 / \mathrm{wk}$ & $\mathrm{Lc}$ & Yes & 36 \\
\hline & $65 \mathrm{M}, 297 \mathrm{~F}$ aged 47 & $21 \mathrm{wk}, 10000 \mathrm{steps} /$ day & $\mathrm{L}$ & Yes & 37 \\
\hline & $46 \mathrm{~F}$ aged $20-40$ & $24 w k, 56,67$ or $86 \%$ & $\mathrm{~L}$ & Yes & 40 \\
\hline & $17 \mathrm{~F}$ aged $20-40$ & $11 \mathrm{wk}, 71 \% \mathrm{HRmax}$ & $\mathrm{Lc}$ & Yes & 52,53 \\
\hline & $24 \mathrm{~F}, 8 \mathrm{M}$ aged 68 & $9 \mathrm{wk}, 57,70 \% \mathrm{~V}_{2} \max$ & $\mathrm{Lc}$ & Yes & 57 \\
\hline & $35 \mathrm{~F}$ aged $25-45$ & $15 \mathrm{wk}$, brisk walk & $\mathrm{Lc}$ & No & 58 \\
\hline & $32 M$ aged $52-88$ & $6 w k$, mixed programme & $\mathrm{L}$ & Yes & 59 \\
\hline & $7 \mathrm{M}$ aged $52-88$ & $42 \mathrm{wk}$, mixed programme & $\mathrm{L}$ & Yes & 59 \\
\hline & $23 \mathrm{~F}$ aged $52-79$ & $13 \mathrm{wk}$, mixed programme & $\mathrm{Lc}$ & Yes & 60 \\
\hline & $64 \mathrm{M}$ aged $40-60$ & $12 w k, 42-60$ or $63-81 \%$ & L & Yes & 61 \\
\hline & $44 \mathrm{~F}$ aged 44.9 & $52 \mathrm{wk}, 6.5 \mathrm{~km} / \mathrm{h}$ & Lc & Yes@2mmol/lactate & 62 \\
\hline & $\begin{array}{l}14 \mathrm{M}, 12 \mathrm{~F} \text { aged } \\
35-53\end{array}$ & $12 \mathrm{wk}, 60 \% \dot{\mathrm{VO}}_{2} \max$ & $\mathrm{Lr}$ & Yes & 63 \\
\hline & $44 \mathrm{M}$ aged 22 & $2 \mathrm{wk}, 10-30 \mathrm{~km} / \mathrm{day}$ & $\mathrm{L}$ & Yes (submax) & 64 \\
\hline & $14 \mathrm{~F}, 1 \mathrm{M}$ aged 16 & $3 / \mathrm{wk}, 11$ weeks & $\mathrm{L}$ & Yes & 65 \\
\hline & $24 \mathrm{~F}$ aged $67-89$ & $10 \mathrm{wk}, 40,60 \%$ HRres & $\mathrm{L}$ & Yes & 66 \\
\hline \multirow[t]{10}{*}{ Osteoporosis } & $73 \mathrm{~F}$ & & $\mathrm{Lc}$ & No (wrist) & 66 \\
\hline & $17 \mathrm{~F}$ aged $49-64$ & $62 \% \dot{\mathrm{V}}_{2} \max 5 / \mathrm{wk}$ & $\mathrm{Lc}$ & No & 67 \\
\hline & $229 \mathrm{~F}$ aged $50-60$ & Walk $11 \mathrm{~km} / \mathrm{wk} 3 \mathrm{yr}$ & $\mathrm{Lc}$ & No (wrist) & 68 \\
\hline & $36 \mathrm{~F}$ aged 60.2 & $52 \mathrm{wk}$, weighted belt & $\mathrm{Lc}$ & Yes with $\mathrm{Ca}^{2+}$ & 69 \\
\hline & $280 \mathrm{~F}, 120 \mathrm{M}$ & $\begin{array}{l}\text { Case-control (femoral } \\
\text { fractures) }\end{array}$ & & Yes & 70 \\
\hline & 239 post menopause & $12 \mathrm{~km} / \mathrm{wk} v<1.6 \mathrm{~km} / \mathrm{wk}$ & $\mathrm{C}$ & Yes & 71 \\
\hline & $F$ aged $30-60$ & $52 \mathrm{wk}, 2.5 \mathrm{~h} / \mathrm{wk}$ & $\mathrm{Lc}$ & Yes & 72 \\
\hline & $33 \mathrm{~F}$ aged $45-67$ & $30 \mathrm{wk}$, walking & $\mathrm{Lc}$ & Yes ( $>$ anaerobic threshold) & 73 \\
\hline & $162 \mathrm{~F}$ & Aerobics + walking & $\mathrm{L}$ & Yes with $\mathrm{Ca}^{2+}$ & 74 \\
\hline & 619 aged 70 & Daily $30 \mathrm{~min}$ walk & C & Yes & 75 \\
\hline \multirow{2}{*}{ Mental health } & $35 \mathrm{~F}$ aged $25-45$ & $15 \mathrm{wk}$, brisk walking & $\mathrm{L}$ & Yes & 58 \\
\hline & $19 \mathrm{~F}, 17 \mathrm{M}$ aged 37 & $\begin{array}{l}\text { Single walk } \\
55-72 \% \dot{\mathrm{V}}_{2} \max \end{array}$ & $\mathrm{C}$ & & 76 \\
\hline
\end{tabular}

$\mathrm{C}=$ cross-sectional study $\mathrm{L}=$ longitudinal study $\mathrm{Lc}=$ longitudinal controlled study $\mathrm{Lr}=$ randomised longitudinal controlled study $M=$ male; $F=$ female; $w k=$ weeks; $H R=$ heart rate; $\max =$ maximum; res = resting; $H D L=$ high density lipoprotein.

Those likely to benefit from such an approach have tended to be sedentary, ${ }^{4755566377}$ obese, ${ }^{3748}$ and elderly. ${ }^{39465254575960656869}$ In such individuals, even a period of deliberate walking in a shopping mall may demand $70-80 \%$ of maximal oxygen intake. ${ }^{39}$ Porcari et $a l^{78}$ noted that $91 \%$ of women and $83 \%$ of men over the age of 50 years reached a training heart rate while carrying out unpaced walking "as fast as possible".

Walking does not usually increase muscle strength. ${ }^{45}$ Nevertheless, it seems to yield important functional gains in the frail elderly.
Specifically, an association has been noted between a regular daily 30 minute walk and the ability to climb stairs. ${ }^{75}$

\section{Amount of activity required for cardiovascular health}

If an exercise programme is very intense, then quite short sessions may be sufficient to enhance cardiovascular health. However, with more moderate lifestyle programmes, a substantial total volume of physical activity is required for benefit. Recent position state- 
ments have been developed from both occupational and leisure studies.

\section{OCCUPATIONAL STUDIES}

An early review of occupational data suggested that a daily work site energy expenditure of 1.7-3.8 MJ (400-900 kcal) was needed to enhance health related fitness and reduce cardiovascular or overall mortality. ${ }^{79}$ If such an energy expenditure had been distributed uniformly over an entire working day, it would have boosted energy expenditure by an average of only $4-8 \mathrm{~kJ} / \mathrm{min}(1-2 \mathrm{kcal} / \mathrm{min})$.

In some jobs, health benefits have reflected periods of relatively high intensity effort, interspersed with relaxation breaks or rest pauses But in other occupations such as postal carriers, ${ }^{80}{ }^{81}$ the benefit appears to be due to several hours per day of moderate and relatively uniform activity at gross intensities of 20 $\mathrm{kJ} / \mathrm{min}(5 \mathrm{kcal} / \mathrm{min})$ or less. ${ }^{82}$

\section{STUDIES OF ACTIVE LEISURE}

The minimum intensity of effort required in order to improve cardiovascular health is likely to be greater in active leisure than when at work, because the duration of most active leisure pursuits is shorter than a normal eight hour workday.

Traditionally, physiologists who were interested in developing cardiovascular fitness called for intensities of exercise near to the ventilatory threshold, a level of physical activity that is likely to boost the aerobic power of the average sedentary person by as much as $20 \%{ }^{83}{ }^{84}$ On the other hand, several recent papers have suggested that much of the desired increase in health related fitness can be attained by exercising at much lower intensities of effort, possibly insufficient to induce any increase in aerobic power. ${ }^{3-12} 85$ Moreover, with the important exception of a study of British civil servants, ${ }^{14}$ the largest gain in cardiovascular prognosis was seen on moving from individuals in the lowest to those in the next higher category of physical activity or aerobic fitness. ${ }^{85}$

Additional health benefits associated with progression to much higher levels of physical activity or fitness have been disappointingly small. The activity related benefit was greater in two investigations where differences in habitual physical activity were inferred from measurements of aerobic fitness than in other studies where activity patterns were estimated from questionnaire responses. ${ }^{85}$ Indeed, self reports of walking were not associated with any protection against hypertension. ${ }^{86}$ Two recent studies $^{87} 88$ compared cardiac risk factors with reported physical activity and physical fitness in the same subjects; in confirmation of the inferences from interstudy comparisons, the relationship to cardiac risk factors was closer for fitness than for physical activity.

This does not necessarily mean that one must increase aerobic fitness in order to enhance health. It could also be that patterns of physical activity are indicated more precisely by the measurement of aerobic fitness than by activity questionnaires.
RECENT POSITION STATEMENTS

Recent quasi-experimental data on the health benefits of moderate activity led the American College of Sports Medicine (ACSM) to modify an earlier "position stand", reducing the recommended minimum intensity of the aerobic component of an exercise prescription to $50 \%$ of aerobic power, practiced for one hour three to five times per week. ${ }^{11}$ The revised recommendation is now supported by the American Heart Association and by the US Surgeon General. In an average $75 \mathrm{~kg}$ middle aged man with an aerobic power of $35 \mathrm{ml} / \mathrm{kg}$ per min, the revised standard implies that health needs will on average be satisfied by an energy expenditure of about 5 METS, 27 $\mathrm{kJ} / \mathrm{min}$ or $6.5 \mathrm{kcal} / \mathrm{min}$ where $1 \mathrm{MET}$ is an oxygen consumption of about $3.5 \mathrm{ml} / \mathrm{kg}$ per $\mathrm{min}$ at resting metabolic rate.

Because the peak aerobic power declines progressively with age, the intensity corresponding to $50 \%$ of aerobic power drops to around $3 \mathrm{METS}, 19 \mathrm{~kJ} / \mathrm{min}$, or $4.5 \mathrm{kcal} / \mathrm{min}$ in an elderly or an unfit individual. One corollary of this age differential is that elderly, sedentary, obese, and disabled individuals are the groups most likely to benefit from low intensity exercise programmes.

Although most studies have focused upon the minimum intensity and duration of effort required for cardiovascular health, active living has the potential to enhance many other aspects of health (table 2). The key to obtaining some of these benefits, such as the control of body fat content, may be the absolute energy expenditure per week rather than the intensity of effort that is chosen. ${ }^{89}$

\section{Activity generated by an active lifestyle}

Even the currently advocated minimum intensity of activity for health (5 METS in middle aged adults) seems fairly demanding relative to the energy cost of commonly reported voluntary leisure pursuits such as walking and cycling.

\section{WALKING}

The most commonly reported self-imposed leisure activity is walking. ${ }^{20}$ There is a general relationship between the self selected walking pace and aerobic power $(r=0.64) .^{78}$ In part because of a waning aerobic power, many older people progressively decrease their walking speed. ${ }^{90}$ By the eighth decade, the typical woman regards $3.2 \mathrm{~km} / \mathrm{h}(2 \mathrm{mph})$ as a comfortable walking speed..$^{91}$ But making the assumption that the average adult adopts a walking pace of $4.8 \mathrm{~km} / \mathrm{h}$, then the gross energy cost is likely to be around $19 \mathrm{~kJ} / \mathrm{min}(12 \mathrm{ml}$ of oxygen consumption/kg per $\mathrm{min}$ ) in a man of $75 \mathrm{~kg} .{ }^{92-94}$ This intensity of effort plainly meets the new ACSM standard ${ }^{10}$ in the case of elderly subjects, but is inadequate for young or middle aged individuals.

Morris and Hardman ${ }^{95}$ have maintained that a prescription of "brisk" walking is appropriate to maintain physical fitness. In their experience, ${ }^{5396}$ such a recommendation generally yields a pace that is some $60 \%$ of aerobic power; if asked to walk a mile $(1.6 \mathrm{~km})$ as fast 
as possible, two thirds of adult men and $90 \%$ of women attain a heart rate in the optimal training zone ( $70 \%$ of maximal or greater). People are unlikely to walk as fast as possible in the course of their ordinary leisure, but they might do so if the activity was a part of their normal journey to and from work.

In order to develop the targeted gross expenditure of 5 METS (a net energy expenditure of $4 \mathrm{METS}$, or $14 \mathrm{ml} / \mathrm{kg}$ per $\mathrm{min}$ ), a young or middle aged person would need to attain an unrealistically high walking pace of $140 \mathrm{~m} / \mathrm{min}$, $8.4 \mathrm{~km} / \mathrm{h}$, or $5.2 \mathrm{mph}$. Other options for reaching the 5 MET standard include jogging, or walking on soft or uneven terrain. Walking up a $5 \%$ gradient increases energy expenditure by $50 \%$ and descent of a hill demands almost as much energy as walking on the level; energy costs may also increase $2-3$ fold when walking in snow. ${ }^{94}$

\section{CYCLING AND OTHER LEISURE ACTIVITIES}

Cycling is another commonly reported lifestyle activity. ${ }^{20}$ If the cyclist adopts a speed of 16 $\mathrm{km} / \mathrm{h}(10 \mathrm{mph})$, the net energy cost is typically $29 \mathrm{~kJ} / \mathrm{min}$, an adequate intensity for maintenance of good health. Other activities of appropriate intensity include skiing at 4.0 $\mathrm{km} / \mathrm{h}$, swimming at $25 \mathrm{~m} / \mathrm{min}$, walking upstairs, the heaviest forms of gardening, sawing hardwood, and chopping wood. ${ }^{97}$ However, the majority of recreational activities and domestic chores fall below even the revised ACSM requirements.

\section{PHYSIOLOGICAL RESPONSES}

Table 2 summarises physiological responses to walking.

Duncan et $a l^{40}$ compared strolling at 4.8 $\mathrm{km} / \mathrm{h}$, brisk walking at $6.4 \mathrm{~km} / \mathrm{h}$ and aerobic walking at $8 \mathrm{~km} / \mathrm{h}$. The subjects, women aged 20-40 years, were followed for 24 weeks. Gains of aerobic power increased with walking speed, but the threshold for benefit was the relatively rapid pace of $5.6 \mathrm{~km} / \mathrm{h}(4 \mathrm{mph})$. In contrast, decreases in body fat and total cholesterol were as large with moderate as with brisk exercise.

Hopkins et $a l^{p 8}$ studied randomly selected adult New Zealanders. They noted that "hard" physical activity (as assessed by either their own CORE questionnaire ${ }^{98}$ or the Stanford questionnaire) was correlated relatively strongly with aerobic power $(r=0.40)$, a decrease in skinfold $(r=0.22)$, vital capacity $(r$ $=0.19)$, and protection against exercise induced myocardial ischaemia $(r=0.14)$. However, improvements in lipid profile were seen only when subjects walked a minimum of $13 \mathrm{~km} /$ week $^{51}$; no protection was found in subjects reporting only "low" intensities of physical activity.

DiPietro et al ${ }^{99}$ examined adults aged $60-86$ years. In their study, vigorous leisure activity was correlated with aerobic power; in contrast, leisure walking and the total leisure activity showed a modest correlation with body fat, but not with aerobic power.
COMMUTING AS A MOTIVATING FORCE

Can the time pressures of commuting generate the sense of urgency that is needed to reach an appropriate intensity of physical activity when a person is walking or cycling?

Sallis $e t a l^{100}$ noted that such activities as getting off the bus early or parking some distance away from one's destination were associated with favourable cardiac risk factor profiles among 5930 participants in the Stanford five city trial. But too often, potential commuter cyclists are deterred by the unpleasantness of cycling in traffic and the difficulty in finding a secure place to park bicycles. ${ }^{101}$ Vuori et al ${ }^{24}$ asked a small group of Tampere citizens who normally drove to work to adopt either walking or cycling as their method of commuting for a ten week period. Almost all of those who were contacted accepted the proposal for a ten week trial. Commuting boosted physical activity by 30 minutes or more in each direction every day. The pace chosen by the cyclists corresponded to an oxygen consumption of $23-24 \mathrm{ml} / \mathrm{kg}$ per $\mathrm{min}$, in the range $65-70 \%$ of aerobic power for a sedentary middle aged adult. The walking speed of $5.7 \mathrm{~km} / \mathrm{h}$ was also relatively brisk, but probably commanded an oxygen consumption of no more than $13 \mathrm{ml} / \mathrm{kg}$ per min, only about $37 \%$ of aerobic power. The average heart rates during the journey were 131 and 121 beats/ min, corresponding to 65 and $55 \%$ of aerobic power. Presumably, the heart rates of the walkers were augmented by a combination of heat, hills, and the carrying of a briefcase.

The chosen speed of habitual walkers may be somewhat higher than that of the sedentary volunteers who were recruited by Vuori et al. ${ }^{24}$ Spelman $e t \mathrm{al}^{102}$ found an average walking speed of $6.4 \mathrm{~km} / \mathrm{h}$, corresponding to $52 \%$ of aerobic power (5.2 METS) in 22 women and seven men aged 35 (9) years (mean (SD)); the total increase in weekly energy expenditure due to walking was 4.7 (2.0) MJ.

\section{Empirical response to structured and unstructured programmes} WEIGHT LOSS

The Behavioral Risk Factor Surveillance System survey of 1989 provides data showing the impact of various types of physical activity upon subjects who were attempting to decrease their body mass. ${ }^{103}$ Unfortunately, data on participation in aerobics programmes were included only for women. The loss of weight from unstructured running was as great, and that from unstructured cycling was almost as great, as that for formal aerobics programmes. In contrast, unstructured walking and gardening only seemed to induce weight loss in the older (and presumably the less fit) members of the group.

\section{WORK SITE EXERCISE PROGRAMMES}

Work site exercise programmes provide much information on the response to structured physical activity, although the interpretation of results is complicated because most programmes have included a variety of health promotional options in addition to exercise. ${ }^{104}$ Moreover, the random allocation of subjects to 
experimental and control groups is rarely possible in the workplace, and many work site studies have been uncontrolled. Finally, results are usually available only for a small residue of high adherents to the programme, so that any benefits tend to be exaggerated. ${ }^{105}$

Perhaps the best work site study was that conducted at the Johnson \& Johnson Corporation. ${ }^{106}$ This averaged the response of all employees at the test locations. Over a two year period, a well financed and well organised structured programme of aerobic exercise yielded a $2 \%$ decrease in body fat, a $6 \%$ increase in aerobic power, a $7 \%$ decrease in serum cholesterol, a $4 \mathrm{~mm} \mathrm{Hg}$ decrease in systolic blood pressure, and a $1 \mathrm{~mm} \mathrm{Hg}$ decrease in diastolic blood pressure. Such benefits are smaller than those seen among individuals who themselves select an active lifestyle, but at least in terms of aerobic power are greater than what has been achieved by asking volunteers to walk or cycle to work for three months.

\section{SUPERVISED ACTIVITY IN THE HOME}

King et $a l^{107}$ made a direct comparison of the efficacy of a structured versus a supervised home based programme in women and men aged 50-65 years. Probably in part because of the lesser time demands of home based activities, programme adherence over a one year period was much better than for structured exercise. Perhaps for this same reason the female subjects achieved larger gains of aerobic power with the home based than with the structured programme. However, changes in body mass and blood lipids were not significant for either type of exercise.

\section{ISSUES OF AGE, GENDER, AND ETHNICITY}

How are conclusions regarding an appropriate dose of physical activity modified by issues of age, gender, and ethnic group? The primary influence of such factors upon the health response to physical activity comes from any peculiarities in the initial fitness of the target group. To the extent that the elderly, women, and minority groups enter trials with a low level of fitness, such individuals should gain more than average benefit from a programme of moderate physical activity, whether this be structured or unstructured. Thus rapid walking is much more likely to benefit an elderly immigrant woman than a young white man.

Against the potential advantage of a low initial level of fitness, there are obvious problems in recruitment and compliance for the groups identified. Moreover, the manner of participation in either structured or unstructured activities shows age, gender, and ethnic related differences. For example, a young person on average walks or cycles at a higher speed than an older adult. Data from the Behavioral Risk Factor Survey suggest that unstructured activities are on the increase in women and in the elderly, but are decreasing in poorly educated and minority groups. ${ }^{108} 109$
SAFETY CONSIDERATIONS

Children sustain a substantial proportion of their physical injuries during unstructured exercise. ${ }^{110}$ However, in adults, one of the attractions of walking and similar activities is that the injury rate is extremely low relative to most other activities. Thus Pollock et al ${ }^{111}$ noted that a deliberate 13-week exercise programme gave rise to only one injury in 57 healthy men and women aged $70-80$ years.

\section{Conclusions}

Current data suggest that structured exercise programmes may have a somewhat greater effect upon health than unstructured leisure activity, particularly in young adults. However, it is easier to encourage unstructured activity, and thus there remains a need for a well designed and sustained prospective trial that compares the impact of the two approaches to physical activity in closely matched groups of subjects. Further information is needed on how far the relative efficacy of structured and unstructured programmes differs between children, young men, women, and older adults. However, present evidence suggests that moderate lifestyle activity will enhance health in elderly, sedentary, and obese groups, but not in young adults who are in good initial health.

These studies are supported by a research grant from Canadian Tire Acceptance Limited. 1 Bouchard C, Shephard RJ, Stephens T, Sutton J, McPher-
son B. Exercise, fitness and health. Champaign, IL: Human Kinetics Publishers, 1990.

2 Bouchard C, Shephard RJ, Stephens T. Physical activity, fitness and health. Champaign, IL: Human Kinetics Publishers, 1994

3 Blair SN, Kohl HW, Paffenbarger RS et al. Physical fitness and all-cause mortality: a prospective study of healthy men and women. $\mathcal{F} A M A$ 1989;262:2395-401.

4 Blair SN, Kohl HW, Barlow CE et al. Changes in physical fitness and all-cause mortality: a prospective study of healthy and unhealthy men. $\mathscr{F} A M A$ 1995;273:1093-8.

5 Ekelund LG, Haskell WL, Johnson JL et al. Physical fitness as a predictor of cardiovascular mortality in asymptomatic Follow-up Study. N Engl f Med 1988;319:1379-84.

6 Leon AS, Connett J, Jacobs DR et al. Leisure-time physical activity levels and risk of coronary heart disease and death: activity levels and risk of coronary heart disease and death:
the Multiple Risk Factor Intervention Trial. $f A M A$ the Multiple Risk

7 Lie H, Mundal R, Erikssen J. Coronary risk factors and Lie H, Mundal R, Erikssen J. Coronary risk factors and
incidence of coronary death in relation to physical fitness: seven-year follow-up of study of middle-aged and elderly men. Eur Heart f 1985;6:147-57.

8 Sandvik L, Erikssen J, Thaulow E et al. Physical fitness as a predictor of mortality among healthy, middle-aged Norwegian men. N Engl $\mathcal{F}$ Med 1993;328:533-7.

9 Shaper AG, Wannamethee G. Physical activity and ischaemic heart disease in middle-aged British men. Br Heart $\mathcal{f}$ 1991;66:384-94.

10 American College of Sports Medicine. The recommended quantity and quality of exercise for developing and maintaining fitness in healthy adults. Med Sci Sports Exerc 1991;22:265-74.

11 American College of Sports Medicine. Guidelines for graded exercise testing and exercise prescription. 5 th ed. Philadelphia: Lea \& Febiger, 1995.

12 US Surgeon General. Physical activity and health. Atlanta, GA: US Department of Health and Human Services, Centers for Disease Control and Prevention, National Center for Chronic Disease Prevention and Health Promotion, 1996.

13 Haapanen N, Miilunpalo S, Vuori I et al. Characteristics of leisure time physical activity associated with decreased risk of premature all-cause and cardiovascular disease mortality in middle-aged men. Am $\mathcal{F}$ Epidemiol 1996;143:870-80.

14 Morris JN, Clayton DG, Everitt MG et al. Exercise in leisure time: coronary attack and death rates. Br Heart $\mathcal{F} 1990 ; 63$ 325-34.

15 Lee I-M, Hsieh CC, Paffenbarger RS. Exercise intensity and longevity in men: the Harvard Alumni Health Study. fAMA 1995;273:1 179-84

16 Lakka TA, Venalainen JM, Rauramaa R et al. Relation of leisure-time physical activity and cardiorespiratory fitness to the risk of acute myocardial infarction in men. $N$ Engl $\mathcal{F}$ Med 1994;330:1549-54. 
17 Slattery ML, Jacobs DR, Nichaman MZ. Leisure time physical activity and coronary heart disease death: the U.S physical activity and coronary heart disease deat

18 Dishman R. Exercise adherence. Champaign, IL: Human Kinetics Publishing, 1995.

19 Dishman R, Buckworth J. Increasing physical activity: a quantitative synthesis. Med Sci Sports Exerc 1996;28:70619.

20 Stephens T, Craig C. The well-being of Canadians: the 1988 Campbell's Survey. Ottawa: Canadian Fitness \& Lifestyle Research Institute, 1990.

21 Hillsdon M, Thorogood M, Anstiss T, Morris J. Randomized controlled trials of physical activity promotion in free-living populations: a review. $\mathcal{f}$ Epidemiol Community Health 1995;49:448-53.

22 Blamey A, Mutrie N, Aitchison T. Health promotion by encouraged use of stairs. BMF 1995;311:289-90.

23 Brownell KD, Stunkard AJ, Albaum JM. Evaluation and modification of exercise patterns in a natural environment. Am $\mathcal{F}$ Psychiatry 1980;137:1540-5.

24 Vuori IM, Oja P, Paronen M. Physically active commuting to work: testing its potential for exercise promotion. Med Sci Sports Exerc 1994;26:844-50.

25 Young DR, Haskell WL, Taylor CB, Fortmann SP. Effect of community health education on physical activity knowl edge, attitudes and behavior. Am $\mathcal{f}$ Epidemiol 1996;144: edge, at

26 Powell KE, Thompson PD, Caspersen CJ, Kendrick JS Physical activity and the incidence of coronary hear disease. Annu Rev Public Health 1987;8:253-87.

27 Wyndham $\mathrm{CH}$. An examination of the methods of physica classification of African labourers for manual work. $S A f$ Med F 1972;46:251-7.

28 Morris JN, Heady J, Raffle P. Physique of London busmen Lancet 1956;ii:569-70.

29 Brunner D, Manelis G. Physical activity at work and ischemic heart disease. In: OA Larsen, RO Malmborg, eds. Coronary heart disease and physical fitness. Baltimore: Coronary heart disease and
University Park Press, 1971 .

30 Berlin JA, Coldlitz GA. A meta-analysis of physical activity in the prevention of coronary heart disease. Am $\mathcal{f}$ Epidemio 1990;132:612-18.

31 Rauramaa R, Tuomainen P, Väisänen S, Raukinen T. Physical activity and health-related fitness in middle-aged men. Med Sci Sports Exerc 1995;27:707-12.

32 Gardner AW, Poehlman ET. Leisure time physical activity is a significant predictor of body density in men. $\mathcal{F}$ Clin Epidemiol 1994;47:283-91.

33 Hickey N, Mulcahy R, Bourke GJ et al. Study of coronary risk factors related to physical activity in $15,171 \mathrm{men} . B M \mathcal{F}$ risk factors relat

34 Cooper KH, Pollock ML, Martin RP et al. Physical fitnes levels vs selected coronary risk factors: a cross-sectional study. $¥ A M A$ 1976;236:166-9.

35 Shephard RJ, Bouchard C. Population evaluations of health related fitness from perceptions of physical activity and fitness. Can F Appl Physiol 1994;19:151-73.

36 Davison RCR, Grant S, Mutrie N et al. Walk for health? $\mathcal{f}$ Sports Sci 1992;10:556(Abstr).

37 Ohta T, Kawamura T, Hatano K et al. Effects of exercise on coronary risk factors in obese, middle-aged subjects. $f_{p n}$ Circ f 1990;54:1459-64.

38 Pollock ML, Miller HS, Janeway R et al. Effects of walking on body composition and cardiovascular function of middle-aged men. f Appl Physiol 1971;30:126-30.

39 Whitehurst M, Menendez E. Endurance training in older women. Lipid and lipoprotein responses. Physician and women. Lipid and lipoprotein

40 Duncan JJ, Gordon NF, Scott CB. Women walking for health and fitness. How much is enough? $\mathcal{F} A M A$ 1991;266: 3295-9.

41 Ready EA, Naimark B, Ducas J et al. Influence of walking volume on health benefits in women post-menopause. Med Sci Sports Exerc 1996;28:1097-105.

42 Hagberg JM, Montain SJ, Martin WH et al. Effect of exercise training in 60- to 69-year-old persons with essential hypertension. Am F Cardiol 1989;64:348-53.

43 Seals Dr, Reiling MJ. Effect of regular exercise on 24-hour arterial pressure in older hypertensive humans. Hypertension 1991;18:583-92.

44 Kingwell BA, Jennings GL. Effects of walking and other exercise programs upon blood pressure in normal subjects. exercise programs upon blood
Med f A A ust 1993;158:234-8.

45 Cononie CC, Graves JE, Pollock ML et al. Effect of exercise training on blood pressure in 70- to 79-year old men and women. Med Sci Sports Exerc 1991;23:505-11.

46 Hamdorf PA, Withers RT, Penhall RK et al. Physical training effects on the fitness and habitual activity patterns of elderly women. Arch Phys Med Rehabil 1992;73:603-8.

47 Hardman AE, Hudson A, Jones PMR et al. Brisk walking and plasma high density lipoprotein cholesterol concentration in previously sedentary women. BMF 1989;290:12045.

48 Leon AS, Conrad J, Humminghake DB et al. Effects of a vigorous walking program on body composition, and carbohydrate and lipid metabolism of obese young men. Am f Clin Nutr 1979;32:1776-87.

49 Cook TC, Laporte RE, Washburn RA et al. Chronic low level physical activity as a determinant of high density lipoprotein cholesterol and subfractions. Med Sci Sports Exerc 1986;18:653-7.

50 Tucker LA, Friedman GM. Walking and serum cholesterol in adults. Am F Public Health 1990;80:1111-13.
51 Wood PD, Haskell WL, Blair SN et al. Increased exercise level and plasma lipoprotein alterations: a one-year level and plasma lipoprotein alterations. a one-year men. Metabolism 1983;32:31-9.

52 Santiago MC, Alexander JF, Stull GA et al. Physiologica responses of sedentary women to a 20 -week conditioning programme of walking or jogging. Scandinavian fournal of Sports Science 1987;9:33-9.

53 Stensel DJ, Brooke-Wavell K, Hardman AE et al. The influence of a one year programme of brisk walking on endurance fitness and body composition in previously sedentary men aged 42-59 years. Eur $\mathcal{f}$ Appl Physio 1994;68:531-7.

54 White KM, Yeater RA, Martin RB et al. Effects of aerobic dancing and walking on cardiovascular function and muscular strength in postmenopausal women. 7 Sports Med cular strength in

55 Hardman AE, Jones PRM, Norgaan NG et al. Brisk walking improves endurance fitness without changing body fatnes in previously sedentary men. Eur $\mathcal{F}$ Appl Physiol 1992; 65:354-9.

56 Rowland TW, Varzeas MR, Walsh CA. Aerobic responses to walking training in sedentary adolescents. 7 Adolesc Healt 1991;12:30-4.

57 Badenhop DT, Cleary PA, Schaal SF et al. Physiological adjustments to higher or lower intensity exercise in elders. Med Sci Sports Exerc 1983;15:496-502.

58 Cramer SR, Nieman DC, Lee JW. The effects of moderate exercise training on psychological well-being and mood state in women. Psychosomatic Research 1991;35:437-49.

59 de Vries HA. Physiological effects of an exercise trainin regimen upon men aged 52 to 88 . F Gerontol 1970;25:32536.

60 Adams GM, deVries HA. Physiological effects of an exercise training regimen upon women aged 52 to 79.7 Gerontol 1973;28:50-5.

61 Gossard D, Haskell WL, Barr-Taylor C et al. Effects of low and high intensity home based exercise training on functional capacity in healthy middle aged men. $\mathrm{Am} \mathrm{f} \mathrm{Car}$ functional capacity

62 Hardman AE, Hudson A, Jones PMR et al. Brisk walking influences the physiological responses to submaximal step test in women. F Physiol (Lond) 1989;409:22P

63 Jetté M, Sidney KH, Campbell J. Effects of twelve-week walking programme on maximal and submaximal work output indices in sedentary middle-aged men and women. f Sports Med Phys Fitness 1988;28:59-66.

64 Durnin JVGA, Brockway JM, Whitcher HW. Effects of a short period of training of varying severity on some measurements of physical fitness. F Appl Physiol 1960;15:161-5.

65 Miyashita M. Haga S, Mizuta T. Training and detraining effects on aerobic power in middle aged and older men. $\mathcal{f}$ effects on aerobic power in middle aged
Sports Med Phys Fitness 1978;18:131-7.

66 Foster VL, Hume JGE, Byrnes WC et al. Endurance training for elderly women. Moderate vs low intensity. $\mathcal{J}$ Gerontol 1989;44M:184-8.

67 Cavanaugh DJ, Cann CE. Brisk walking does not stop bone loss in postmenopausal women. Bone 1988;9:201-4

68 Sandler RB, Cauley JA, Hom DL et al. The effects of walking on the cross-sectional dimensions of the radius in postmenopausal women. Calcif Tissue Int 1987;41:65-9.

69 Nelson M, Fisher E, Dilmanian F et al. A 1-year walking program and increased dietary calcium in postmenopausal
women; effects on bone. Am f Clin Nutr 1991;53:1304-11.

70 Lau E, Donnan S, Barker DJP et al. Physical activity and calcium intake in fracture of the proximal femur in Hong Kong. BMF 1988;297:441

71 Krall EA, Dawson-Hughes B. Walking is related to bone density and rates of bone loss. Am f Med 1994;96:20-6.

72 Jones PRM, Hardman AE, Hudson A et al. Influence of brisk walking on the broadband ultrasonic attenuation of the calcaneus in previously sedentary women aged 30-61 years. Calcif Tissue Int 1991;49:112-15.

73 Hatori M, Hasegawa A, Adachi $\mathrm{H}$ et al. The effects of walking at the anaerobic threshold level on vertebral bone loss in post-menopausal women. Calcif Tissue Int 1993:52:41114.

74 White MK, Martin RB, Yeater RA et al. The effects of exercise on the bones of post-menopausal women. International cise on the bones of post-menthopaedics 1984;7:209-14.
Orthop

75 Frändin K, Grimby G, Mellström D et al. Walking habits and health-related factors in a 70-year-old population. Gerontology 1991;37:281-8.

76 Porcari J, Ward A, Morgan W et al. Effect of walking on state anxiety and blood pressure. Med Sci Sports Exerc 1988;20 S85(Abstr)

77 Morgan WP, Roberts JA, Feinermann AD. Psychological effect of acute physical activity. Phys Med Rehabil 1971;52: 422-5.

78 Porcari J, McCarron R, Kline G et al. Is fast walking an adequate aerobic stimulus for 30 to 69 -year-old men and women? Physician and Sportsmedicine 1987;15:119-29.

79 Fox SM, Skinner JS. Physical activity and cardiovascular health. Am f Cardiol 1964;14:731-46.

80 Morris JN, Raffle PAB. Coronary heart disease in transport workers: Progress report. $B r \mathcal{F}$ Ind Med 1954;11:260-4.

$81 \mathrm{Kahn} \mathrm{H}$. The relationship of reported coronary heart disease mortality to physical activity of work. Am $\mathcal{f}$ Public
Health 1963;53:1058-67.

82 Shephard RJ. The workload of the postal carrier. 7 Hum Ergol (Tokyo) 1983;11:151-64.

83 Shephard RJ. Endurance fitness. 1st ed. Toronto: University of Toronto Press, 1969. 
84 American College of Sports Medicine. The recommended quantity and quality of exercise for developing and quantity and quality of exercise for developing and maintaining

85 Blair SN, Connelly JC. How much physical activity should we do? The case for moderate amounts and intensities of physical activity. Res $Q$ 1996;67:193-20

86 Paffenbarger RS, Wing AL, Hyde RT et al. Physical activity and incidence of hypertension in college alumni. Am $\mathcal{F ~ E p i - ~}$ demiol 1983;117:245-57.

87 Lochen ML, Rasmussen K. The Tromso study. Physical fitness, self-reported physical activity and their relationship to other coronary risk factors. $\mathcal{f}$ Epidemiol Community Health 1992;46:103-7.

88 Young DB, Steinhardt MA. The importance of physical fitness versus physical activity for coronary heart disease risk ness versus phsical activity for coronary heart disease risk

89 Ballor DL Kesey RA. A metasis. Res $Q 1$ 1 in ing exercise-induced changes in body mass, fat mass and fat-free mass in males and females. Int f Obes 1991;15:71726.

90 Himann JE, Cunningham DA, Rechnitzer PA et al. Age-related changes in speed of walking. Med Sci Sports
Exerc 1988;20:161-6.

91 Danneskold-Samsoe B, Kofod V, Munter J et al. Muscle strength and functional capacity in 78-81 year old men and women. Eur 7 Appl Physiol 1984;52:310-14.

92 Mahadeva K, Passmore R, Woolf $B$. Individual variations in the metabolic cost of standardized exercises: the effects of food, age, sex and race. F Physiol (Lond) 1953;121:225-31.

93 Goodman J, Goodman L. Exercise prescription for the sedentary adult. In: P Welsh, RJ Shephard, eds. Current therapy in sports medicine 1985-1986. Philadelphia: BC Decker, in sports medici

94 Durnin JVGA, Passmore R. Energy, work and leisure. London: Heinemann, 1967.

95 Morris JN, Hardman AE. Walking to health. Sports Med 1997 ; in press

96 Hardman AD, Hudson A, Jones PRM et al. Brisk walking improves endurance fitness without changing body fatness in previously sedentary women. Eur f Appl Physiol 1992;65: 354-9.

97 Wynder EL. The book of health. American Health Foundation. New York: Franklin Watts, 1981

98 Hopkins WG, Wilson NC, Russell DG. Validation of the physical activity instrument for the Life in New Zealand National Survey. Am f Epidemiol 1991;133:73-82.
99 DiPietro L, Caspersen CJ, Ostfeld A et al. A survey for assessing physical activity among older adults. Med Sci Sports Exerc 1993;25:628-42.

100 Sallis JF, Haskell WL, Fortmann SP et al. Moderate intensity physical activity and cardiovascular risk factors: the Stanford five-city project. Prev Med 1986;15:561-8.

101 Bhopal R, Unwin N. Cycling, physical exercise and the Millenium Fund. BMF 1995;311:344.

102 Spelman CC, Pate RR, Macera CA et al. Self-selected exercise intensity of habitual walkers. Med.Sci. Sports Exerc 1993;25:1174-9.

103 DiPietro L, Williamson DF, Caspersen CJ et al. The descriptive epidemiology of selected physical activities and body weight among adults trying to lose weight: the Behavioral Risk Factor Surveillance System Survey, 1989. Int $\mathcal{F}$ Obes 1993;17:69-76.

104 Shephard RJ. A critical analysis of work-site fitness programs and their postulated economic benefits. Med $S c i$ Sports Exerc 1992;24:354-70.

105 Shephard RJ. Worksite fitness and exercise programs: a review of methodology and health impact. American fournal of Health Promotion 1996;10:116-32.

106 Blair SN, Piserchia PV, Wilbur CS et al. A public health intervention model for work site health promotion: impact on exercise and physical fitness in a health promotion plan after 24 months. FAMA 1986;255:921-6.

107 King A, Haskell WL, Taylor B et al. Group- vs home-based exercise training in healthy older men and women. A community-based clinical trial. $7 A M A 1991 ; 266: 1535-42$.

108 Caspersen CJ, Merritt RK. Physical activity trends among 26 states, 1986-1990. Med Sci Sports Exerc 1995;27:71320

109 Heath GW, Smith JD. Physical activity patterns among adults in Georgia: results from the 1990 Behavioral Ris Factor Surveillance System. South Med f 1994;87:435-40.

110 Goldberg B, Witman PA, Gleim GW, Nicholas GA. Children's sports injuries: are they avoidable? Physician and Sportsmedicine 1979;7:93-101.

111 Pollock ML, Carroll JF, Graves JE et al. Injuries and adherence to walk/jog and resistance training programs in adherence to walk/jog and resistance training progr

112 Shephard RJ, Bouchard C. Population evaluations of health-related fitness from perceptions of physical activity and fitness. Can $\mathcal{F}$ Appl Physiol 1994;19:151-73. 